\title{
Economic analysis of corn inoculated with Azospirillum brasilense associated with nitrogen sources and doses
}

\author{
Análise econômica do milho inoculado com Azospirillum brasilense \\ associado a doses e fontes de nitrogênio
}

\author{
Fernando Shintate Galindo ${ }^{1 *}$; Marcelo Carvalho Minhoto Teixeira Filho ${ }^{2}$; Maria \\ Aparecida Anselmo Tarsitano ${ }^{2}$; Salatiér Buzetti ${ }^{2}$; José Mateus Kondo Santini1; \\ Mariana Gaioto Ziolkowski Ludkiewicz ${ }^{1}$; Cleiton José Alves ${ }^{3}$; Orivaldo Arf ${ }^{2}$
}

\begin{abstract}
Azospirillum brasilense is a bacterium known for its biological nitrogen fixation (BNF) in corn crops. However, there is a lack of comprehensive research defining how much mineral $\mathrm{N}$ should be applied to maximize the efficiency of BNF and attain high, economically sustainable yields. Moreover, it would be interesting to investigate whether adding urea with NBPT urease inhibitor might increase BNF in grasses. Therefore, the aim of this study was to determine the effect of inoculation with Azospirillum brasilense associated with $\mathrm{N}$ sources and doses in a Cerrado biome soil by evaluating the grain yield of irrigated corn in economic terms. The experiment was conducted in Selvíria, MS, Brazil under a no-till system on a Latossolo Vermelho distrófico (Oxisol). The experiment was set up as a randomized block design with four replications in a $2 \times 5 \times 2$ factorial arrangement consisting of two sources of $\mathrm{N}$ (urea and urea with NBPT urease enzyme inhibitor) and five $\mathrm{N}$ doses applied as top-dressing $(0,50$, 100, 150, and $200 \mathrm{~kg} \mathrm{ha}^{-1}$ ), with and without the inoculation of seeds with $A$. brasilense. Inoculation with Azospirillum brasilense makes corn growth much more profitable, irrespective of the dose and source of N. Addition of $200 \mathrm{~kg} \mathrm{ha}^{-1} \mathrm{~N}$ in the form of conventional urea coupled with inoculation with Azospirillum brasilense increases grain yield; however, the highest economic return is obtained with $\mathrm{N}$ applied at $100 \mathrm{~kg} \mathrm{ha}^{-1}$ with conventional urea and inoculation.
\end{abstract}

Key words: Fertilizer with improved efficiency. Nitrogen fertilization. No-tillage system. Total operational cost. Urea. Zea mays.

\section{Resumo}

O Azospirillum brasilense se destaca na fixação biológica de nitrogênio (FBN) em cultivo de milho. Contudo, faltam maiores pesquisas para definição do quanto se pode aplicar de $\mathrm{N}$ mineral quanto à eficiência da FBN, para alcançar altas produtividades economicamente sustentáveis. Além disso, seria interessante analisar se a ureia com inibidor da enzima urease NBPT pode ser menos prejudicial, beneficiando a FBN em gramíneas. Sendo assim, objetivou-se estudar o efeito da inoculação com Azospirillum brasilense, associado às doses e fontes de N, em solo de Cerrado, avaliando economicamente a produtividade de grãos de milho irrigado. O experimento foi desenvolvido em Selvíria - MS, em sistema plantio direto, em Latossolo Vermelho distrófico. O delineamento experimental foi em blocos

\footnotetext{
${ }^{1}$ Discentes Curso de Doutorado, Programa de Pós-Graduação em Agronomia, Universidade Estadual Paulista, UNESP, Campus de Ilha Solteira, Ilha Solteira, SP, Brasil. E-mail: fs.galindo@yahoo.com.br; santinijmk@gmail.com; mariana.gaioto@gmail.com

2 Profs. Drs., UNESP, Ilha Solteira, SP, Brasil. E-mail: mcmtf@yahoo.com.br; maat@agr.feis.unesp.br; sbuzetti@agr.feis.unesp. br; arf@agr.feis.unesp.br

${ }^{3}$ Discente Curso de Doutorado, Programa de Pós-Graduação em Agricultura, UNESP, Botucatu, SP, Brasil. E-mail: cleiton.agr. feis@gmail.com

* Author for correspondence
} 
casualizados, com quatro repetições, dispostos em um esquema fatorial 2 × 5 x 2 , sendo: duas fontes de $\mathrm{N}$ (ureia e ureia com inibidor da enzima urease NBPT); cinco doses de $\mathrm{N}$ em cobertura $(0,50,100,150$ e $200 \mathrm{~kg} \mathrm{ha}^{-1}$ ); com e sem inoculação das sementes com A. brasilense. A inoculação com Azospirillum brasilense torna o cultivo de milho mais lucrativo, independentemente da dose e fonte de $\mathrm{N}$. A dose de $200 \mathrm{~kg} \mathrm{ha}^{-1}$ de $\mathrm{N}$ na forma de ureia convencional associado à inoculação com Azospirillum brasilense proporciona maior produtividade de grãos, entretanto, o maior retorno econômico é obtido na dose de $100 \mathrm{~kg} \mathrm{ha}^{-1}$ de N, com ureia convencional e inoculação.

Palavras-chave: Adubação nitrogenada. Custo operacional total. Fertilizante de eficiência aprimorada. Sistema plantio direto. Ureia. Zea mays.

\section{Introduction}

Corn is one of the oldest and most widespread crops in the world. Despite current technological advancements, the average production in Brazil is still too low, at approximately $5,401 \mathrm{~kg} \mathrm{ha}^{-1}$, considering the in-season and off-season harvests. There is a need for improved management techniques so producers can obtain higher yields and consequently greater profit.

To obtain high grain yields from this cereal, high doses of nitrogen $(\mathrm{N})$ must be applied because soils in general cannot meet the requirements of the crop throughout its cycle (CANTARELLA et al., 2008; SOUZA et al., 2011). In non-legume crops, nitrogen fertilization represents one of the highest costs in the production process (NUNES et al., 2015). Wheat, corn, and rice crops consume approximately $60 \%$ of the total nitrogen fertilizer produced in the world (LADHA et al., 2005). Therefore, nitrogen fertilization is utilized to ensure good productivity according to the $\mathrm{N}$ dynamics in the soil by adding large amounts of $\mathrm{N}$, which can raise production costs to farmers (TEIXEIRA FILHO et al., 2014).

The main source of $\mathrm{N}$ used in Brazil is urea, the advantages of which include high $\mathrm{N}$ content and lower price of $\mathrm{N}$ per unit of fertilizer. Additionally, it is highly soluble, less corrosive than other sources, and compatible with many fertilizers. On the other hand, some of its drawbacks are the possibility of $\mathrm{N}$ losses via $\mathrm{NH}_{3}$ volatilization, phytotoxicity of biuret, and leaching losses (CANTARELLA, 2007). In this regard, one possible method to increase the efficiency of $\mathrm{N}$ fertilization is the use of the NBPT inhibitor $(\mathrm{N}-$ (n-butyl) thiophosphoric triamide), which can slow urea hydrolysis and significantly reduce $\mathrm{NH}_{3}$ losses (CANTARELLA et al., 2008).

However, unlike some studies conducted in temperate countries, most research carried out in Brazil has shown that urea applied with a urease enzyme inhibitor and conventional urea have the same efficiency in regard to nutrition and productivity of corn grains. In other words, the inhibitory action of urease has not been completely effective in controlling losses by volatilization of $\mathrm{NH}_{3}$ that occur when urea is applied to the soil surface, given that the action of NBPT depends on the environmental conditions of temperature and precipitation and on the physicochemical properties of the soil (CANTARELLA et al., 2008; SCIVITTARO et al., 2010; GALINDO et al., 2016).

Another factor to be taken into account concerning the high cost of nitrogen fertilizers and the awareness of sustainable and cleaner agriculture that is being researched is the use of bacteria-containing inocula to promote growth and increase plant productivity (HUNGRIA, 2011). There are many studies in the literature confirming that Azospirillum produces phytohormones that stimulate root growth in several plant species (TIEN et al., 1979; BASHAN et al., 2006; BARASSI et al., 2008). However, in most studies involving the inoculation of seeds with Azospirillum ssp., though one or more benefits were detected, increased corn grain yield was not always observed, showing the importance of developing more studies of this nature and evaluating the effects of Azospirillum ssp. on plant nutrition. Furthermore, there have been few investigations of how much mineral $\mathrm{N}$ can be 
applied for successful FBN to increase productivity. It would be interesting to analyze the application of urea with NBPT urease enzyme inhibitor to determine whether it is detrimental with respect to FBN in grasses.

By virtue of the above-stated facts, researchers are concerned with finding viable alternatives to increase the efficiency of nitrogen fertilization, allowing a reduction in nitrogen use without decreasing productivity. However, research demonstrating the effect of $A$. brasilense inoculation associated with sources and doses of $\mathrm{N}$ as top-dressing is rare. Therefore, the aim of this investigation was to conduct an economic analysis of irrigated corn as a function of inoculation with Azospirillum brasilense associated with doses and sources of $\mathrm{N}$ applied as top-dressing in a lowaltitude Cerrado biome region.

\section{Material and Methods}

The experiment was conducted during the crop years of 2013/14 and 2014/15 in an experimental area belonging to the Faculty of Engineering at UNESP, located in Selvíria, MS, Brazil (335 m asl). The soil of the experimental area was classified as a Latossolo Vermelho distrófico (Oxisol) with clayey texture, according to Santos et al. (2013) and had been cultivated with annual crops for over 27 years, with the last 10 years under the no-till system, and the crops prior to corn were black oat and then wheat. Precipitation, air relative humidity, and the maximum, mean, and minimum temperatures recorded during the experimental period are shown in Figure 1.

For both crops, a randomized-block design with four replications was set up in a $2 \times 5 \times 2$ factorial arrangement consisting of two sources of $\mathrm{N}$ (conventional urea, with $45 \% \mathrm{~N}$ ); Super $\mathrm{N}^{\circledR}$
- urea with NBPT urease enzyme inhibitor (N (n-butyl thiophosphoric triamide), with 45\% N); five $\mathrm{N}$ doses $\left(0,50,100,150\right.$, and $\left.200 \mathrm{~kg} \mathrm{ha}^{-1}\right)$ applied as top-dressing on the corn inter-rows with or without inoculation of seeds with $A$. brasilense. Experimental plots comprised seven 6-m long rows spaced $0.45 \mathrm{~m}$ apart, with the five central rows as the usable area of the plot and excluding $0.5 \mathrm{~m}$ of extremities.

The herbicides glyphosate $\left(1800 \mathrm{~g} \mathrm{ha}^{-1}\right.$ of the active ingredient [a.i.]) and 2,4-D (670 $\mathrm{g} \mathrm{ha}^{-1}$ of the a.i.) were used for the desiccation of the agricultural area. The soil chemical attributes in the arable layer were determined before the implementation of the corn experiment in 2013, following the methodology proposed by Raij et al. (2001). The following results were obtained: $13 \mathrm{mg} \mathrm{dm}^{-3} \mathrm{P}$ (resin); $6 \mathrm{mg}$ $\mathrm{dm}^{-3} \mathrm{~S}_{-} \mathrm{SO}_{4} ; 23 \mathrm{~g} \mathrm{dm}^{-3} \mathrm{OM}$; pH $4.8\left(\mathrm{CaCl}_{2}\right)$; K, $\mathrm{Ca}$, $\mathrm{Mg}, \mathrm{H}+\mathrm{Al}=2.6,13.0$., 8.0, and $42.0 \mathrm{mmol}_{\mathrm{c}} \mathrm{dm}^{-3}$, respectively; $\mathrm{Cu}, \mathrm{Fe}, \mathrm{Mn}$, and $\mathrm{Zn}(\mathrm{DTPA})=5.9$, $30.0,93.9$, and $1.0 \mathrm{mg} \mathrm{dm}^{-3}$, respectively; $0.24 \mathrm{mg}$ $\mathrm{dm}^{-3} \mathrm{~B}$ (hot water); and $36 \%$ base saturation.

Based on the soil chemical analysis and aiming to increase the base saturation to $70 \%$, as recommended by Cantarella et al. (1997), $2.5 \mathrm{t}$ dolomitic limestone $($ PRNT $=88 \%)$, were applied 65 days before the corn was sown in 2013, as top-dressing and without incorporation. During fertilization at planting, for both crop years of the experiment, $400 \mathrm{~kg} \mathrm{ha}^{-1}$ of the 08-28-16 formulation was used, corresponding to $32 \mathrm{~kg} \mathrm{ha}^{-1} \mathrm{~N}, 112 \mathrm{~kg} \mathrm{ha}^{-1} \mathrm{P}_{2} \mathrm{O}_{5}$, and $64 \mathrm{~kg} \mathrm{ha}^{-1} \mathrm{~K}_{2} \mathrm{O}$, based on the soil analysis and the requirements of the corn crop.

Inoculation of corn seeds with the bacterium Azospirillum brasilense strains AbV5 AbV6 (provides $2 \times 10^{8} \mathrm{cfu}^{-1}$ ) was performed using a 200-mL inoculum (liquid) per hectare of seeds with the aid of a mixer for better incorporation of the inoculum into the seeds one hour before sowing. 
Figure 1. Rainfall, air relative humidity and maximum, average and minimum temperatures obtained from the weather station located in the Education and Research Farm of FE / UNESP during the maize cultivation in the period December 2013 to April 2014 (A) and December 2014 to April 2015 (B).

(A)

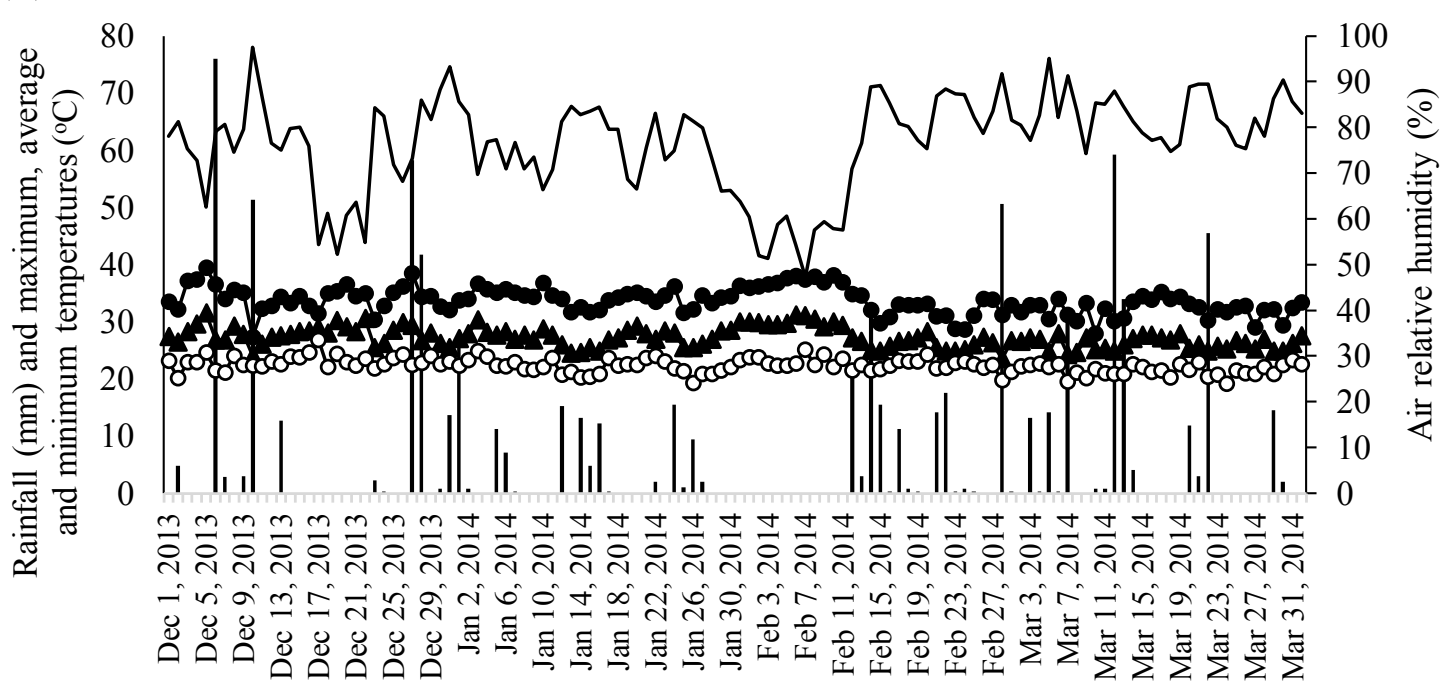

(B)

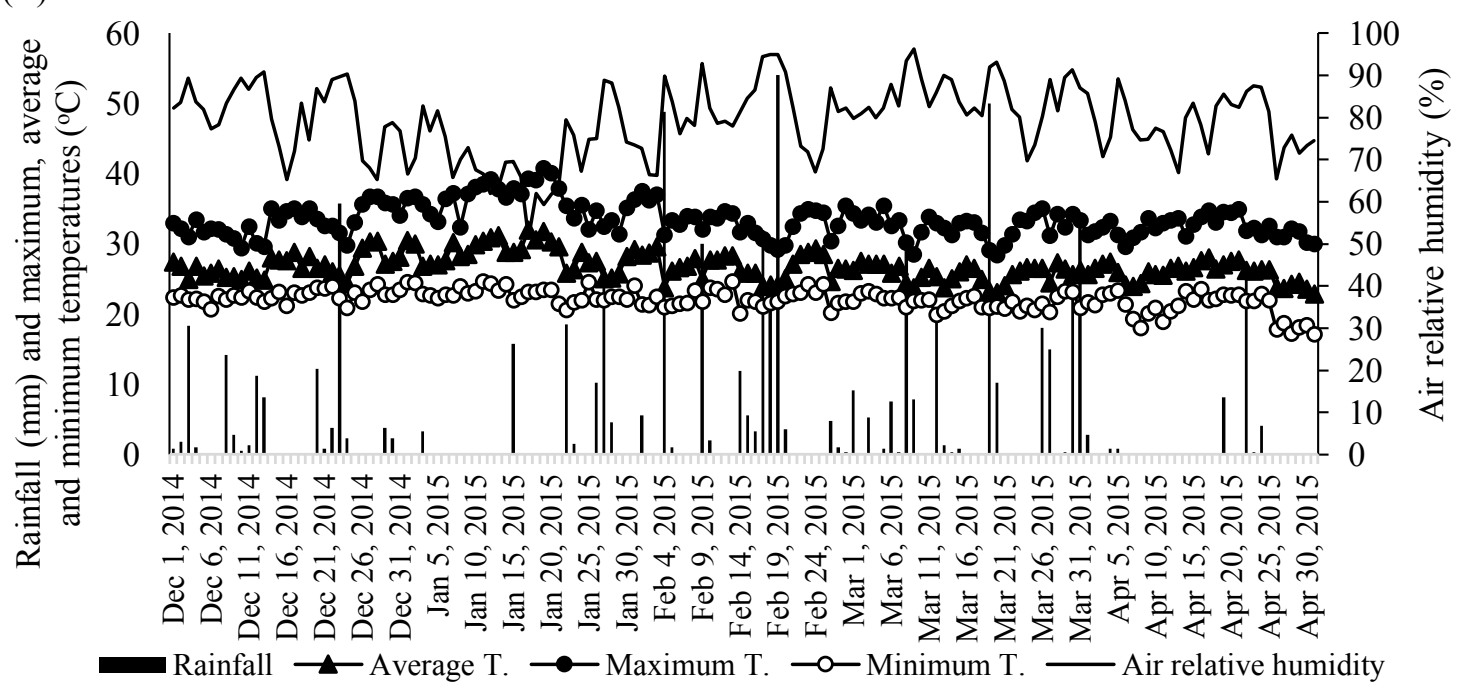

The triple-hybrid corn DKB 350 VT PRO (resistant to the fall armyworm [Spodoptera frugiperda]) was mechanically sown on 12/04/2013 in the $2013 / 14$ crop and on $12 / 02 / 2014$ in the $2014 / 15$, at three seeds per meter, and seedling emergence occurred five days after seeding, on 12/09/2013 and 12/07/2014, respectively. To control post-emergence weeds, the herbicides tembotrione ( $84 \mathrm{~g} \mathrm{ha}^{-1}$ of a.i.) and atrazine (1,000 $\mathrm{g} \mathrm{ha}^{-1}$ of the a.i.) were applied, and an adjuvant, vegetable oil (720 g ha $^{-1}$ of the a.i.), was added to the herbicide spray on $01 / 02 / 2014$ and $12 / 28 / 2014$, respectively. Insect control was performed with methomyl (215 $\mathrm{g} \mathrm{ha}^{-1}$ of the a.i.) and triflumurom ( $24 \mathrm{~g} \mathrm{ha}^{-1}$ of the a.i.) on $01 / 15 / 2014$ and $01 / 11 / 2015$, respectively. Whenever necessary, irrigation was applied via spraying, using a center pivot with an average water depth of $14 \mathrm{~mm}$ and an irrigation interval of approximately $72 \mathrm{~h}$.

Top-dressing nitrogen (treatments) was applied by broadcasting without incorporation into the soil 
in the corn inter-rows on $01 / 08 / 14$ and $01 / 04 / 15$, when the plants had six fully extended leaves (V6). The fertilizer was applied manually, distributed over the soil surface (without incorporation) on the sides and at approximately $10 \mathrm{~cm}$ from the rows, aiming to avoid contact with plants. The harvest occurred on 03/28/2014 and 04/04/2015, i.e., 108 and 120 days after corn emergence, respectively.

Ten corn ears were collected at harvest for determination of the following variables: number of kernels per ear, obtained by counting the kernels on each ear, from each experimental unit; 100-kernel weight, determined on a $0.01 \mathrm{~g}$ precision scale at $13 \%$ (wet basis); and grain yield, determined by collecting the plants contained in the usable area of each plot. After mechanical harvesting, kernels were quantified and data were transformed into $\mathrm{kg}$ $\mathrm{ha}^{-1}$ and corrected for $13 \%$ moisture (wet basis) and transformed into $60-\mathrm{kg}$ sacks. The results were subjected to analysis of variance and Tukey's test at 5\% probability for comparison of means of $\mathrm{N}$ sources and use or non-use of inoculation with Azospirillum brasilense and adjusted to regression equations for the effect of $\mathrm{N}$ doses in SISVAR software.

For the economic analysis, the metric total operating production costs (TOC) used by the Institute of Agricultural Economics (IEA) were adopted, according to Matsunaga et al. (1976). This measure consists of the sum of operating expenses: operations performed, inputs (fertilizers, seeds, pesticides, etc.), labor, machinery, and irrigation and was termed effective operating costs (EOC). Other operating expenses and interests, amounting to $5 \%$ of the EOC (MATSUNAGA et al., 1976), were also included to yield the total operating cost (TOC), which was extrapolated to one hectare. This methodology has been already used in several studies on economic evaluation in crops such as Kaneko et al. (2010), Garcia et al. (2012), Leal et al. (2013), Kappes et al. (2015), Portugal et al. (2016).
To determine the profitability of the involved treatments, profitability analyses were carried out following Martin et al. (1998). To this end, the following variables were determined: gross revenue (GR) (in $\mathrm{R} \$$ ), as the product of the amount produced (in number of $60-\mathrm{kg}$ sacks) by the average sale price (in $\mathrm{R} \$$ ); operating profit (OP), as the difference between the gross revenue and total operating cost; accumulated operating profit (AOP), as the sum of the OP obtained in the two years of study; profitability index (PI), understood as the ratio between operating profit (OP) and the net revenue (NR), as a percentage; equilibrium price, given a certain total operating production cost, as a the minimum price calculated to cover this cost, considering the average productivity of the producer; and equilibrium yield, given a certain total operating production cost, as the minimum productivity to cover this cost, considering the average price paid to the producer.

The average prices were quoted in the region of Selvíria - MS, Brazil, in 2015 average of the year (IEA, 2016). In this study, simulations were performed as if each experimental treatment represented commercial crops. To help expand on the data, especially concerning the machine-hour dose, the machine yield, the inputs utilized, and the price of the sack of corn, the grain producers of the region were interviewed concerning the prices paid for the inputs for the 2015/2016 crop. To facilitate the discussion, the values referring to the yields were transformed into $60-\mathrm{kg}$ sacks, which was the basic unit of sale by local producers. The cost of the sack of corn for the municipality of Selvíria was $\mathrm{R} \$ 24.00$ per unit produced. As regards the $\mathrm{N}$ sources, the price paid by the farmer was $\mathrm{R} \$ 1,780.00$ and $\mathrm{R} \$ 2,000.00$ per ton for urea and urea with urease enzyme inhibitor in the region, respectively. For the inoculum with Azospirillum brasilense, the expenditure was around $\mathrm{R} \$ 10.00$ per dose, and two doses were used per hectare in both corn crops. 


\section{Results and Discussion}

Increased $\mathrm{N}$ doses did not independently influence the number of kernels per ear, 100-kernel weight in 2013/14, or grain yield (Table 1). By contrast, the increased $\mathrm{N}$ doses provided a linear increase in 100-kernel weight in 2014/15. Maestrelo et al. (2014) also found that the increase in $\mathrm{N}$ doses was associated with a linear increase (up to $120 \mathrm{~kg}$ ha $^{-1} \mathrm{~N}$ ) the 100-kernel weight.

Table 1. Number of kernels per ear, 100-kernel weight and grain yield of corn affected by doses and sources of nitrogen, with or without inoculation with Azospirillum brasilense (2013/14 and 2014/15). Selvíria - MS.

\begin{tabular}{|c|c|c|c|c|c|c|}
\hline \multirow[t]{2}{*}{$\mathrm{N}$ doses $\left(\mathrm{kg} \mathrm{ha}^{-1}\right)$} & \multicolumn{2}{|c|}{ Number of kernels per ear } & \multicolumn{2}{|c|}{ 100-kernel weight (g) } & \multicolumn{2}{|c|}{$\begin{array}{c}\text { Grain yield } \\
\text { (60-kg sacks) }\end{array}$} \\
\hline & $2013 / 14$ & $2014 / 15$ & $2013 / 14$ & $2014 / 15$ & $2013 / 14$ & $2014 / 15$ \\
\hline 0 & 620 & 538 & 31.67 & $29.16^{(1)}$ & 136.9 & 93.5 \\
\hline 50 & 652 & 525 & 31.75 & 29.81 & 145.2 & 92.6 \\
\hline 100 & 631 & 559 & 31.48 & 30.04 & 153.6 & 105.4 \\
\hline 150 & 655 & 561 & 32.26 & 30.30 & 152.1 & 114.4 \\
\hline 200 & 650 & 560 & 32.12 & 31.33 & 153.1 & 121.1 \\
\hline \multicolumn{7}{|l|}{$\mathrm{N}$ sources } \\
\hline Urea & $642 \mathrm{a}$ & $552 \mathrm{a}$ & $31.83 \mathrm{a}$ & $29.68 \mathrm{~b}$ & $148.9 \mathrm{a}$ & $103.0 \mathrm{a}$ \\
\hline Super N & $641 \mathrm{a}$ & $545 \mathrm{a}$ & $31.88 \mathrm{a}$ & $30.58 \mathrm{a}$ & $147.4 \mathrm{a}$ & $107.8 \mathrm{a}$ \\
\hline $\operatorname{LSD}(5 \%)$ & 19 & 27 & 0.69 & 0.55 & 7.5 & 13.4 \\
\hline \multicolumn{7}{|l|}{ Inoculation } \\
\hline With Azospirillum & 640 & $557 \mathrm{a}$ & $31.99 \mathrm{a}$ & $30.14 \mathrm{a}$ & 154.2 & 116.2 \\
\hline Without Azospirillum & 643 & $540 \mathrm{a}$ & $31.72 \mathrm{a}$ & $30.12 \mathrm{a}$ & 142.1 & 94.6 \\
\hline D.M.S (5\%) & 19 & 27 & 0.69 & 0.55 & 7.5 & 13.4 \\
\hline Overall mean & 642 & 549 & 31.86 & 30.13 & 148.2 & 105.4 \\
\hline CV $(\%)$ & 6,76 & 9,57 & 4.82 & 4.10 & 11.33 & 28.31 \\
\hline \multicolumn{7}{|l|}{ F test } \\
\hline $\mathrm{D}$ & $1.936^{\mathrm{ns}}$ & $1.115^{\mathrm{ns}}$ & $0.717^{\mathrm{ns}}$ & $6.636^{* *}$ & $2.891^{*}$ & $2.847^{*}$ \\
\hline S & $0.001^{\mathrm{ns}}$ & $0.296^{\mathrm{ns}}$ & $0.021^{\mathrm{ns}}$ & $10.493^{* *}$ & $0.164^{\mathrm{ns}}$ & $0.528^{\mathrm{ns}}$ \\
\hline I & $0.139^{\mathrm{ns}}$ & $1.488^{\mathrm{ns}}$ & $0.597^{\mathrm{ns}}$ & $0.008^{\mathrm{ns}}$ & $10.398^{* *}$ & $10.509^{* *}$ \\
\hline DxS & $1.349^{\mathrm{ns}}$ & $0.440^{\mathrm{ns}}$ & $0.744^{\mathrm{ns}}$ & $0.678^{\mathrm{ns}}$ & $1.140^{\mathrm{ns}}$ & $0.410^{\mathrm{ns}}$ \\
\hline DxI & $2.770^{*}$ & $1.677^{\mathrm{ns}}$ & $0.344^{\mathrm{ns}}$ & $0.488^{\text {ns }}$ & $2.750^{*}$ & $2.671^{*}$ \\
\hline SxI & $0.048^{\text {ns }}$ & $0.716^{\mathrm{ns}}$ & $2.383^{\mathrm{ns}}$ & $0.040^{\mathrm{ns}}$ & $0.020^{\mathrm{ns}}$ & $0.005^{\text {ns }}$ \\
\hline DxSxI & $1.194^{\mathrm{ns}}$ & $0.885^{\mathrm{ns}}$ & $1.939^{\mathrm{ns}}$ & $0.227^{\mathrm{ns}}$ & $0.640^{\text {ns }}$ & $1.645^{\mathrm{ns}}$ \\
\hline
\end{tabular}

Means followed by the same letter in the column do not differ by the Tukey test at $5 \%$. **, * and ns: significant at $\mathrm{p}<0.01$, $0.01<\mathrm{p}<0.05$, and not significant, respectively.

${ }^{(1)} \hat{Y}=29.1601+0.0097 x\left(R^{2}=0.92\right)$.

Responses of number of kernels per ear to nitrogen fertilization vary according to the corn hybrid. Mohammadi et al. (2003) found that kernel weight and number of kernels per ear were the most important components in predicting grain yield. According to Ohland et al. (2005), kernel weight is influenced by genotype, by the availability of nutrients, and by the climatic conditions during the grain fill stages. For Ulger etal.(1995), the production component is highly dependent on $\mathrm{N}$ absorption by the corn, which peaks between the beginning of flowering and the start of grain formation. Nitrogen deficiency, in this period, can contribute to the formation of grains with a lower specific weight because the nutrient is not translocated in adequate amounts. The fact that no variation was observed in kernel weight as a function of $\mathrm{N}$ doses in 2013/14 suggests that the soil made available an amount of 
$\mathrm{N}$ sufficient for good development and fill of grains from the crop, in the said harvest.

Urea and Super $\mathrm{N}^{\circledR}$ did not differ significantly as $\mathrm{N}$ sources in terms of number of kernels per ear, 100-kernel weight in the 2013/14 crop, or grain yield (Table 1), which is partly due to the similar concentrations of leaf nutrients obtained with urea and Super $\mathrm{N}^{\circledR}$ (data not shown) and can be explained by the non-effective action of NBPT due to the high activity of the urease enzyme as a function of the remaining stover from previous crops and the high temperatures recorded (Figure 1).

Similar results were obtained by Soratto et al. (2010), who found no difference in the number of kernels per ear and 100-kernel weight between crops treated with ammonium sulfonitrate, ammonium sulfate, starea, and urea and by Valderrama et al. (2011) and Maestrelo et al. (2014), who concluded that the use of polymer-coated urea did not influence the agronomic characteristics or grain yield of irrigated corn in the soil-climatic conditions of low- altitude Cerrado biome. However, in the 2014/15, Super $\mathrm{N}^{\circledR}$ yielded a slightly higher 100-kernel weight compared with urea (Table 1).

With respect to the isolated effect of $A$. brasilense inoculation, there was no significant influence on number of kernels per ear and 100-kernel weight (Table 1), corroborating Kappes et al. (2013), who also did not observe an effect of this inoculation via seed on kernel weight and number of kernels per ear.

The interaction between dose and inoculation was significant for the number of kernels per ear in the 2013/14 crop, in which, with $\mathrm{N}$ applied at 200 $\mathrm{kg} \mathrm{ha-1}$, the non-inoculated treatments produced a larger number of kernels per ear than did the treatment inoculated with $A$. brasilense (Table 2). Production in non-inoculated treatments increased linearly as a function of $\mathrm{N}$ doses. No such pattern was seen for $A$. brasilense inoculation because at the zero $\mathrm{N}$ dose (control), inoculation contributed to a greater number of kernels per ear.

Table 2. Inoculation and nitrogen doses interaction for number of kernels per ear of corn. Selvíria - MS, $2013 / 2014$.

\begin{tabular}{cccccc}
\hline \multirow{2}{*}{ Inoculation } & \multicolumn{5}{c}{$\mathrm{N}$ doses $\left(\mathrm{kg} \mathrm{ha}^{-1}\right)$} \\
\cline { 2 - 6 } & 0 & 50 & 100 & 150 & 200 \\
\hline With $^{\text {ns }}$ & $633 \mathrm{a}$ & $647 \mathrm{a}$ & $635 \mathrm{a}$ & $657 \mathrm{a}$ & $628 \mathrm{~b}$ \\
Without $^{*}$ & $608 \mathrm{a}$ & $657 \mathrm{a}$ & $628 \mathrm{a}$ & $653 \mathrm{a}$ & $672 \mathrm{a}$ \\
\hline LSD (5\%) & & 43 & & \\
\hline
\end{tabular}

Means followed by the same letter in the column do not differ by the Tukey test at $5 \%$.**, and ns: significant at $\mathrm{p}<0.01,0.01<\mathrm{p}<0.05$, and not significant, respectively.

$\hat{\mathrm{Y}}=618.4015+0.2498 \mathrm{x}\left(\mathrm{R}^{2}=0.60\right)$.

According to Cruz and Carneiro (2003), the strain is responsible for $50 \%$ of the variation in final grain yield. Thus, in order for the hybrid to express its full genetic potential, the water, nutrients, and temperature factors are fundamental. Increased $\mathrm{N}$ doses in the non-inoculated treatments resulted in greater development of the rows and grains, with a positive impact on the plant's nutritional status. When the treatments were inoculated, an increase in $\mathrm{N}$ doses did not influence these variables. This result is indicative of the ability of $A$. brasilense inoculation to improve nutrient and water absorption, thus improving development of the ear.

The interaction between $\mathrm{N}$ dose and inoculation was significant for corn yield in 2013/14 and 2014/15 (Table 3). Analyzing the effect of the interaction between doses and inoculation on grain yield in 2013/14, with $\mathrm{N}$ applied at $100 \mathrm{~kg} \mathrm{ha}^{-1}$, inoculation with $A$. brasilense improved production (Table 3). Inoculation with $A$. brasilense yielded an increasing linear function according to increasing $\mathrm{N}$ doses; however, there was no such trend for the uninoculated crops. 
Table 3. Inoculation and nitrogen doses interaction for grain yield of corn. Selvíria - MS, 2013/2014 and 2014/2015.

\begin{tabular}{|c|c|c|c|c|c|}
\hline \multirow{3}{*}{ Inoculation } & \multicolumn{5}{|c|}{$2013 / 2014$} \\
\hline & \multicolumn{5}{|c|}{$\mathrm{N}$ doses $\left(\mathrm{kg} \mathrm{ha}^{-1}\right)$} \\
\hline & 0 & 50 & 100 & 150 & 200 \\
\hline With $^{* *}$ & $138.7 \mathrm{a}$ & $150.3 \mathrm{a}$ & $162.7 \mathrm{a}$ & $159.6 \mathrm{a}$ & $159.9 \mathrm{a}$ \\
\hline Without ${ }^{\text {ns }}$ & $135.1 \mathrm{a}$ & $140.2 \mathrm{a}$ & $144.4 \mathrm{~b}$ & $144.6 \mathrm{a}$ & $146.3 \mathrm{a}$ \\
\hline \multirow[t]{2}{*}{ LSD (5\%) } & \multicolumn{5}{|c|}{16.8} \\
\hline & \multicolumn{5}{|c|}{$2014 / 2015$} \\
\hline \multirow{2}{*}{ Inoculation } & \multicolumn{5}{|c|}{$\mathrm{N}$ doses $\left(\mathrm{kg} \mathrm{ha}^{-1}\right)$} \\
\hline & 0 & 50 & 100 & 150 & 200 \\
\hline With $^{* *}$ & $93.5 \mathrm{a}$ & $103.1 \mathrm{a}$ & $121.4 \mathrm{a}$ & $132.9 \mathrm{a}$ & $130.2 \mathrm{a}$ \\
\hline Without $^{\mathrm{ns}}$ & $93.5 \mathrm{a}$ & $82.1 \mathrm{a}$ & $89.4 \mathrm{~b}$ & $95.9 \mathrm{~b}$ & $112.0 \mathrm{a}$ \\
\hline LSD (5\%) & \multicolumn{5}{|c|}{29.9} \\
\hline
\end{tabular}

Means followed by the same letter in the column do not differ by the Tukey test at $5 \%$. **, ${ }^{*}$ and ns: significant at $\mathrm{p}<0.01$, $0.01<\mathrm{p}<0.05$, and not significant, respectively.

$\hat{\mathrm{Y}}=143.9197+0.1031 \times\left(\mathrm{R}^{2}=0.69\right)$

$\hat{\mathrm{Y}}=95.5607+0.2063 x\left(\mathrm{R}^{2}=0.90\right)$.

In 2014/15, at doses of 100 and $150 \mathrm{~kg} \mathrm{ha}^{-1}$, higher grain yields were associated with inoculation with $A$. brasilense (Table 3 ). The yield on inoculated crops fitted an increasing linear function with increasing $\mathrm{N}$ doses. Although there was no statistically significant difference between the lowest and the highest $\mathrm{N}$ doses applied, the positive influence of inoculation on corn grain yield was clear in both harvests.

Positive results with Azospirillum were also reported by Kappes et al. (2013), who evaluated N doses and $A$. brasilense inoculation in the in-season harvest. According to these authors, inoculation provided a $9.4 \%$ increase in grain yield. Cavallet et al. (2000), in turn, observed a $17 \%$ increase in corn yield when seeds were inoculated with Azospirillum spp., with nitrogen top-dressing. The increases in grain yield resulting from inoculation compared with non-inoculation in 2013/14 and 2014/15 were 727 and $1298 \mathrm{~kg} \mathrm{ha}^{-1}$, which corresponds to increases of 12 and 22 sacks of $60 \mathrm{~kg}$, or 8.5 and $22.9 \%$, respectively.

However, Hungria (2011) found that the effects of inoculation of corn seeds on grain yield depend on the genetic traits of plants and on the strains, in addition to environmental conditions. Despite the increased corn grain yield, the effects on grasses are largely variable.

Table 4 shows the structure of the total operating costs (TOC) of the corn crop in the municipality of Selviria, describing the treatment with urea $\mathrm{N}$ at 0 $\mathrm{kg} \mathrm{ha}^{-1}$, without inoculation. This TOC structure model was used in all treatments.

As seen in Table 4, the expenses associated with fertilizers were the highest, followed by those associated with mechanized operations, corresponding to 31.3 and $28.9 \%$ of the TOC, respectively. This outcome is in line with the findings of Kaneko et al. (2010), who studied the viability of the corn crop for the northeast region of São Paulo State in the 2007/2008 and 2008/2009 crops in a notill system with $\mathrm{N}$ management up to the dose of 120 $\mathrm{kg} \mathrm{ha}^{-1}$ and found higher expenditures with fertilizers and mechanized operations, corresponding to 32.74 and $30.91 \%$ TOC, with yields ranging from 85.9 and 146.1 sacks ha ${ }^{-1}$. As $\mathrm{N}$ doses rise and the source changes, the percentage of expenses in relation to the TOC of the fertilizers tends to increase. 
Table 4. Total operating costs structure model of corn for the treatment control (zero $\mathrm{kg} \mathrm{ha}^{-1} \mathrm{~N}$ in top-dressing, as urea form), without inoculation with A. brasilense per hectare. Selvíria - MS, 2013/14 e 2014/15.

\begin{tabular}{|c|c|c|c|c|c|}
\hline Description & Specification $^{1}$ & Times & Amount & Unitary Value (R\$) & Total Value $(\mathrm{R} \$)$ \\
\hline \multicolumn{6}{|l|}{ A. OPERATIONS } \\
\hline Liming & HM & 1.00 & 0.30 & 85.00 & 25.50 \\
\hline Desiccation & HM & 1.00 & 0.50 & 85.00 & 42.50 \\
\hline Hoeing (triton) & HM & 1.00 & 0.50 & 85.00 & 42.50 \\
\hline Seeding & $\mathrm{HM}$ & 1.00 & 1.00 & 110.00 & 110.00 \\
\hline Pulverization & HM & 2.00 & 0.60 & 85.00 & 102.00 \\
\hline Top-dressing & $\mathrm{HM}$ & 1.00 & 0.50 & 85.00 & 42.50 \\
\hline Harvest & $\mathrm{HM}$ & 1.00 & 0.60 & 118.00 & 70.80 \\
\hline Irrigation (pivot) & $\mathrm{mm}$ & 1.00 & 120.00 & 2.50 & 300.00 \\
\hline Subtotal A & & & & & 735.80 \\
\hline \multicolumn{6}{|c|}{ B - AGRICULTURAL INPUT } \\
\hline Dolomitic limestone & $\mathrm{t}$ & 1.00 & 0.63 & 85.00 & 53.13 \\
\hline Fertilizer 08-28-16 & $\mathrm{t}$ & 1.00 & 0.40 & $1,998.00$ & 799.20 \\
\hline Urea & $\mathrm{t}$ & 1.00 & 0.00 & $1,750.00$ & 0.00 \\
\hline Inoculant (A. brasilense) & $\mathrm{L}$ & 1.00 & 0.00 & 10.00 & 0.00 \\
\hline Corn seed DKB 350 YD & $\mathrm{sc}(20 \mathrm{~kg})$ & 1.00 & 1.22 & 450.00 & 549.00 \\
\hline Glyphosate & $\mathrm{L}$ & 1.00 & 4.00 & 14.51 & 58.04 \\
\hline $2,4-\mathrm{D}$ & $\mathrm{L}$ & 1.00 & 1.00 & 13.24 & 13.24 \\
\hline Tembotrione & $\mathrm{L}$ & 1.00 & 0.20 & 403.21 & 80.64 \\
\hline Atrazine & $\mathrm{L}$ & 1.00 & 2.00 & 14.48 & 28.96 \\
\hline Vegetable oil adjuvant & $\mathrm{L}$ & 1.00 & 0.78 & 8.41 & 6.56 \\
\hline Metomyl & $\mathrm{L}$ & 1.00 & 1.00 & 20.59 & 20.59 \\
\hline Triflumuron & $\mathrm{L}$ & 1.00 & 0.05 & 203.19 & 10.16 \\
\hline Subtotal B & & & & & $1,619.52$ \\
\hline \multicolumn{3}{|c|}{ Effective operating costs (EOC) } & & & $2,355.32$ \\
\hline \multicolumn{3}{|c|}{ Other expenses } & & & 117.77 \\
\hline \multicolumn{3}{|l|}{ Interest cost } & & & 76.55 \\
\hline \multicolumn{3}{|l|}{ Total operating cost (TOC) } & & & $2,549.63$ \\
\hline
\end{tabular}

Garcia et al. (2012) worked with the corn crop in the region of Selvíria, using different intercrops with forages and found that the highest expenses were associated with corn seed inputs $(46.46 \%)$, followed by costs associated with fertilization (39.01\%). Greater operating costs were also associated with irrigation via center pivot (45.28\%), with yields varying from 105 to 137 sacks of $60 \mathrm{~kg}$ of corn using urea as the source with $\mathrm{N}$ applied at $100 \mathrm{~kg} \mathrm{ha}^{-1}$.

The costs associated with nitrogen top-dressing as a function of the increasing $\mathrm{N}$ doses ranged from
7.63 to $24.8 \%$ of the TOC for urea and from 8.6 to $27.40 \%$ for Super $\mathrm{N}^{\circledR}$. Examining $\mathrm{N}$ doses $(0$, $45,90,135$, and $180 \mathrm{~kg} \mathrm{ha}^{-1}$ as top-dressing) and sources (urea and coated urea) with and without $A$. brasilense inoculation, Kaneko et al. (2015) found costs with fertilization at planting in the first and second crops to be 31.80 and $24.16 \%$ of the TOC, respectively, with yields ranging from 119 to 191 sacks of $60 \mathrm{~kg}$ of corn. For the costs with $\mathrm{N}$ topdressing, values ranged, in both crops, between 12 and 14 and 16 and $18 \%$ with the urea and coated urea sources, respectively. 
Regarding the TOC and yield of the treatments (Table 5), the highest value for the former was found in the treatment with Super $\mathrm{N}^{\circledR}$ and the $\mathrm{N}$ dose of $200 \mathrm{~kg} \mathrm{ha}^{-1}$ and $A$. brasilense inoculation. The lowest TOC corresponded to the treatments without nitrogen top-dressing $\left(0 \mathrm{~kg} \mathrm{ha} \mathrm{ha}^{-1}\right)$ and without A. brasilense inoculation. However, it is noteworthy that if $\mathrm{N}$ is not replenished in the soil, the soil reserves deplete as the nutrient is extracted, which compromises the productivity of crops over time. The TOC of the treatments that did not receive nitrogen fertilization $\left(0 \mathrm{~kg} \mathrm{ha} \mathrm{ha}^{-1}\right)$ showed equal values, irrespective of the source. This fact occurred because, in the absence of nitrogen fertilization, the relative cost is zero for both sources. The highest values of grain yield were found in the treatment with urea and $\mathrm{N}$ application at $150 \mathrm{~kg} \mathrm{ha}^{-1}$ and $A$. brasilense inoculation in the 2013/14 crop and with Super $\mathrm{N}^{\circledR}$ with $\mathrm{N}$ applied at $150 \mathrm{~kg} \mathrm{ha}^{-1}$ with inoculation in the 2014/15 crop, with average yields of 168 and 146 sacks of $60 \mathrm{~kg}$, respectively.

Table 5. Total operating cost, grain yield and gross revenue of corn affected by doses and sources of nitrogen, with or without inoculation with Azospirillum brasilense. Selvíria MS, 2013/14 and 2014/15.

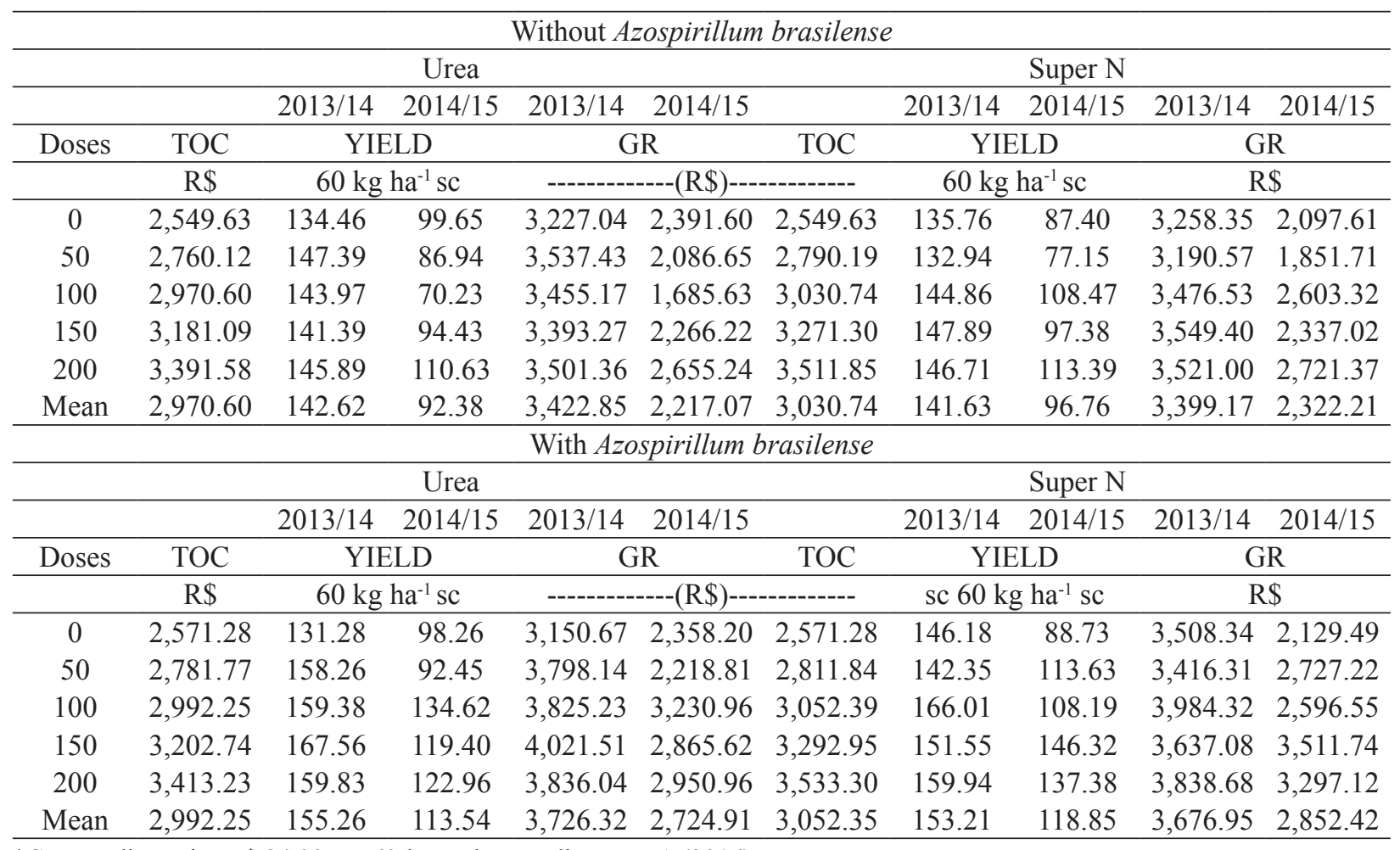

*Corn trading price $\mathrm{R} \$ 24,00$ per $60-\mathrm{kg}$ sack according to IEA (2016).

In both harvests, gross revenues per hectare (Table 5) obtained from combined treatments, the price of corn being constant, the gross revenues of the treatments followed the same trend as the yields (Table 5), i.e., the gains in revenue are due to the increases in grain yield. This result is in agreement with the findings of Silva et al. (2007) and Duete et al. (2009), who found that yield is a primary factor of profitability. As asserted by Duete et al. (2009), even in regions where producers obtain good corn prices, if productivity is low, profitability is compromised. Thus, investment in tmanagement practices, e.g., balanced nitrogen fertilization, improves the grain yield and the gross margin of the corn crop, regardless of the location. 
In the 2013/14 crop, the OP was positive for all studied treatments, irrespective of the dose and source of $\mathrm{N}$, or inoculation (Table 6). In the $2014 / 15$, the operating profit was negative (i.e., loss) in most of the studied treatments, except in the crops treated with $100 \mathrm{~kg} \mathrm{ha}^{-1}$ urea and 150 $\mathrm{kg} \mathrm{ha}^{-1}$ Super $\mathrm{N}^{\circledR}$, both with inoculation (Table 6).
This result is in agreement with those obtained by Gomes et al. (2007), who studied $\mathrm{N}$ top-dressing doses $\left(25,50,100\right.$, and $\left.150 \mathrm{~kg} \mathrm{ha}^{-1}\right)$ with a urea source and obtained negative OP regardless of the dose applied. This variation between harvests was mainly due to the climate of the region (Figure 1); in the 2014/15 crop, these factors were lessened, even with irrigation.

Table 6. Operating profit and profitability index of corn affected by doses and sources of nitrogen, with or without inoculation with Azospirillum brasilense. Selvíria MS, 2013/14 and 2014/15.

\begin{tabular}{|c|c|c|c|c|c|c|c|c|}
\hline \multicolumn{9}{|c|}{ Without Azospirillum brasilense } \\
\hline & \multicolumn{4}{|c|}{ Urea } & \multicolumn{4}{|c|}{ Super N } \\
\hline & $2013 / 14$ & $2014 / 15$ & $2013 / 14$ & $2014 / 15$ & $2013 / 14$ & $2014 / 15$ & $2013 / 14$ & $2014 / 15$ \\
\hline Doses & \multicolumn{2}{|c|}{$\mathrm{OP}$} & \multicolumn{2}{|c|}{ PI } & \multicolumn{2}{|c|}{ OP } & \multicolumn{2}{|c|}{ PI } \\
\hline & \multicolumn{2}{|c|}{$\mathrm{R} \$$} & \multicolumn{2}{|c|}{--------(\%)-------- } & \multicolumn{2}{|c|}{$\mathrm{R} \$$} & \multicolumn{2}{|c|}{------- (\%)------- } \\
\hline 0 & 677.41 & -158.03 & 20.99 & -6.61 & 708.72 & -452.02 & 21.75 & -21.55 \\
\hline 50 & 777.31 & -673.47 & 21.97 & -32.28 & 400.38 & -938.48 & 12.55 & -50.68 \\
\hline 100 & 484.57 & $-1,284.98$ & 14.02 & -76.23 & 445.79 & -427.42 & 12.85 & -16.42 \\
\hline 150 & 212.18 & -914.87 & 6.25 & -40.37 & 278.10 & -934.28 & 7.84 & -39.98 \\
\hline 200 & 109.72 & -736.34 & 3.13 & -27.73 & 9.15 & -790.48 & 0.26 & -29.05 \\
\hline Mean & 452.24 & -753.54 & 13.27 & -36.64 & 368.43 & -708.54 & 11.05 & -31.54 \\
\hline \multicolumn{9}{|c|}{ With Azospirillum brasilense } \\
\hline & \multicolumn{4}{|c|}{ Urea } & \multicolumn{4}{|c|}{ Super N } \\
\hline & $2013 / 14$ & $2014 / 15$ & $2013 / 14$ & $2014 / 15$ & $2013 / 14$ & $2014 / 15$ & $2013 / 14$ & $2014 / 15$ \\
\hline \multirow[t]{2}{*}{ Doses } & \multicolumn{2}{|c|}{ OP } & \multicolumn{2}{|c|}{ PI } & \multicolumn{2}{|c|}{$\mathrm{OP}$} & \multicolumn{2}{|c|}{ PI } \\
\hline & \multicolumn{2}{|c|}{$\mathrm{R} \$$} & \multicolumn{2}{|c|}{--------(\%)-------- } & \multicolumn{2}{|c|}{$\mathrm{R} \$$} & \multicolumn{2}{|c|}{--------(\%)-------- } \\
\hline 0 & 579.39 & -213.80 & 18.39 & -9.04 & 937.08 & -441.79 & 26.71 & -20.75 \\
\hline 50 & $1,016.37$ & -562.96 & 26.76 & -25.37 & 604.47 & -84.62 & 17.69 & -3.10 \\
\hline 100 & 832.98 & 238.71 & 21.78 & 7.39 & 931.93 & -455.84 & 23.39 & -17.53 \\
\hline 150 & 818.77 & -337.12 & 20.36 & -11.76 & 344.13 & 218.79 & 9.46 & 6.23 \\
\hline 200 & 422.81 & -462.27 & 11.02 & -15.67 & 305.58 & -236.18 & 7.98 & -7.16 \\
\hline Mean & 734.06 & -267.49 & 19.66 & -10.89 & 624.64 & -199.93 & 17.05 & -8.46 \\
\hline
\end{tabular}

In the 2013/14 crop, the highest OP was obtained using urea with $\mathrm{N}$ applied at $50 \mathrm{~kg} \mathrm{ha}^{-1}$ and $A$. brasilense inoculation ( $\mathrm{R} \$ 1,016.37)$. For 2014/15, the best result ( $\mathrm{R} \$ 238.71)$ was obtained by using urea with $\mathrm{N}$ applied at $100 \mathrm{~kg} \mathrm{ha}^{-1}$ and $A$. brasilense inoculation (Table 6). While the best outcome was obtained in this harvest, the OP was still much lower than of the previous harvest. If nitrogen fertilization were not used as top-dressing to reduce costs, corn farming would not be viable, given the losses that would occur. This effect highlights the importance of nitrogen fertilization management to achieve high yields and consequently high financial return. Aguiar et al. (2008) found high OP for corn sold in April 2007, grown in a no-till system, without nitrogen fertilization; this result differs partially from the one we obtained in this study. The same was reported by Kaneko et al. (2015), who obtained profitability indices without nitrogen fertilization, with and without inoculation, of 42.36 and $57.84 \%$, respectively. 
In the absence of inoculation, the treatments that provided the highest OP were those without nitrogen fertilization (Table 7). When the crops were inoculated with $A$. brasilense, the highest OP (R $\$ 1,071.69$ ) was obtained with $\mathrm{N}$ applied at $100 \mathrm{~kg}$ ha $^{-1}$, using urea. For Super $\mathrm{N}^{\circledR}$ without inoculation, the highest OP (R \$562.92) was obtained when N was applied at $150 \mathrm{~kg} \mathrm{ha}^{-1}$ (Table 7). OP increased at the end of two years of cultivation with $A$. brasilense inoculation, making the corn crop more profitable, with a $106.2 \%$ increase from the highest OP without inoculation to the treatment that provided the highest OP with inoculation. In turn, Galindo et al. (2017) verified that the co- $A$. brasilense inoculation associated with $\mathrm{Co}+\mathrm{Mo}$ application via seeds promoted higher grain yield and profitability in a soybean crop in the Brazilian Cerrado. This system was technically and economically viable.

Table 7. Accumulated operating profit, equilibrium price and equilibrium yield of corn affected by doses and sources of nitrogen, with or without inoculation with Azospirillum brasilense. Selvíria MS, 2013/14 and 2014/15.

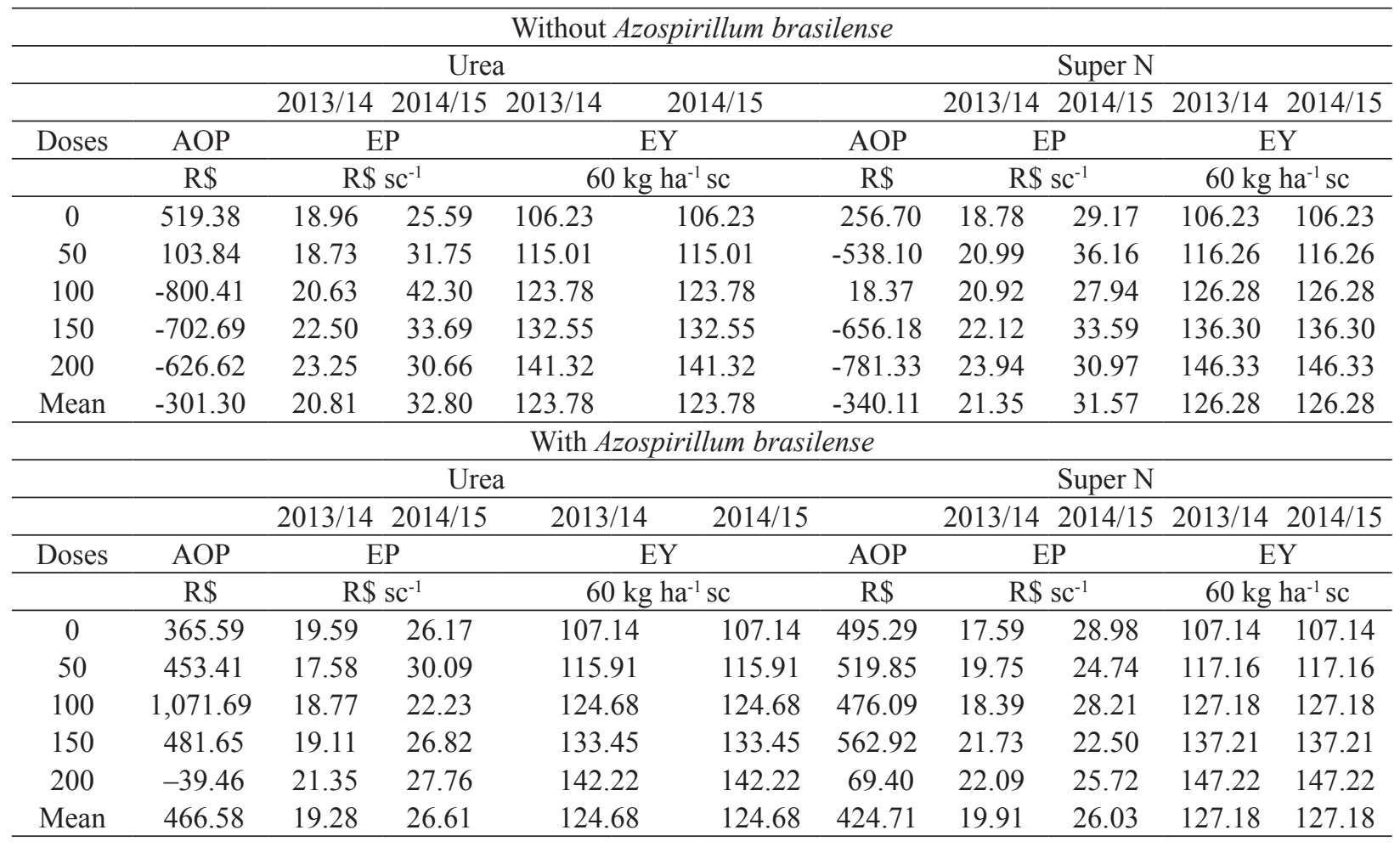

The profitability index followed the same trend as the operating profit (Table 6). In the 2013/14 crop, urea, $\mathrm{N}$ applied at $50 \mathrm{~kg} \mathrm{ha}^{-1}$ and $A$. brasilense inoculation yielded a PI of 26.76. For the 2014/15 crop, urea, $\mathrm{N}$ applied at $100 \mathrm{~kg} \mathrm{ha}^{-1}$ and inoculation yielded a PI of 7.39. Silva et al. (2005) worked with $\mathrm{N}$ top-dressing doses $(30,60,90,120$, and $180 \mathrm{~kg}$ ha $^{-1}$ ) in a no-till system in the Cerrado biome region and yielded a PI between 12.62 and $21.51 \%$, while without nitrogen fertilization, the PI was $-17.37 \%$, a result that reinforces the importance of the nitrogen fertilization management to obtain profitability from the corn crop. Kaneko et al. (2015), on the other hand, found PIs between 42.36 and 51.56, 42.36 and $52.71 ; 39.80$ and 57.84 , and 41.41 and 57.84 with urea and coated urea with and without inoculation, respectively. PIs increased as a function of the $\mathrm{N}$ doses $\left(0,45,90,135\right.$ and $\left.180 \mathrm{~kg} \mathrm{ha}^{-1}\right)$, and those values are higher than those found in this study. 
In the analysis of equilibrium yield (minimum yield to cover the costs), we found that at $\mathrm{R} \$ 24.00$ per sack of $60 \mathrm{~kg}$ of corn, with Super $\mathrm{N}^{\circledR}, 200 \mathrm{~kg}$ $\mathrm{ha}^{-1} \mathrm{~N}$ and $A$. brasilense inoculation, the equilibrium yield was slightly higher (Table 7), at 147.22 sacks $\mathrm{ha}^{-1}$ than it was in the absence of inoculation (146.33 sacks ha ${ }^{-1}$ ). The lowest equilibrium yields were observed when no nitrogen fertilizer was applied: 106.23 and 107.14 sacks without and with A. brasilense inoculation, respectively.

Although the lowest equilibrium yield was obtained in the absence of nitrogen fertilization, failure to supply $\mathrm{N}$ compromises crop yield.

Very little variation was observed between noninoculated and inoculated treatments with regard to equilibrium yield given the same $\mathrm{N}$ doses and sources due to the low cost of the inoculum and of inoculation ( $\mathrm{R} \$ 10.00$ per dose), which is one of the main advantages of inoculation. According to Kaneko et al. (2015), the equilibrium yield ranged from 68 to 89 and 69 to 90 sacks ha ${ }^{-1}$ with urea, without and with inoculation, respectively, and from 68 to 97 and 69 to 98 sacks ha-1 with coated urea, with and without inoculation, respectively, at $\mathrm{N}$ doses of $0,45,90,135$, and $180 \mathrm{~kg} \mathrm{ha}^{-1}$. However, in the region of Chapadão do Sul, MS, Brazil (2009/2010 crop), the equilibrium yield for $\mathrm{R} \$ 12.81$ per 60 $\mathrm{kg}$ corn sack was 158 sacks per ha-1 (KANEKO; LEAL, 2010), demonstrating significant fluctuation in prices and yields in corn-producing regions.

The values (in $\mathrm{R} \$$ ) of the $60-\mathrm{kg}$ corn sack for the equilibrium price (minimum price to cover the TOC) are shown in Table 7. The grains produced with urea had a lower equilibrium price than did those produced using Super $N^{\circledR}$, in both the 2013/14 and 2014/15 crops. Concerning the $\mathrm{N}$ doses, 50 and $100 \mathrm{~kg} \mathrm{ha}^{-1}$ yielded lower equilibrium prices when associated with $A$. brasilense inoculation: $\mathrm{R} \$ 17.58$ and $\mathrm{R} \$ 22.23$ in 2013/14 and in 2014/15, respectively. By contrast, in treatments with Super $\mathrm{N}^{\circledR}$ at the $\mathrm{N}$ rate of $200 \mathrm{~kg} \mathrm{ha}^{-1}(2013 / 14)$ and urea at $100 \mathrm{~kg} \mathrm{ha}^{-1}(2014 / 15)$, both without inoculation, the highest equilibrium prices were $\mathrm{R} \$ 23.94$ and $\mathrm{R} \$ 42.30$, respectively. According to Kaneko et al. (2015), the equilibrium price of a sack of corn ranged from $\mathrm{R} \$ 16.38$ to $\mathrm{R} \$ 18.30$ and $\mathrm{R} \$ 15.33$ to $\mathrm{R} \$ 18.70$ for treatments with urea, with and without inoculation, respectively, and from $\mathrm{R} \$ 14.95$ to $\mathrm{R} \$ 20.29$ and $\mathrm{R} \$ 16.30$ to $\mathrm{R} \$ 20.54$ for treatments with coated urea, with and without inoculation, respectively, as a function of the dose.

Profitability and economic return are strongly associated with $\mathrm{N}$ doses across different crop years and locations, a result that emphasizes the importance of cost and profitability analysis regarding nitrogen fertilization. A. brasilense inoculation is an economically viable alternative, as it combines low cost with increased profitability from the corn crop. For this reason, this technique is likely to be increasingly adopted by rural farmers.

\section{Conclusions}

Inoculation with Azospirillum brasilense makes corn growth more profitable, irrespective of the $\mathrm{N}$ dose and source.

Use of urea with urease enzyme inhibitor is less interesting in economic terms; therefore, it is recommended to use conventional urea, given the ease of its acquisition and greater economic return.

An $\mathrm{N}$ dose of $200 \mathrm{~kg} \mathrm{ha}^{-1}$ in the form of conventional urea, associated with inoculation with Azospirillum brasilense, increases grain yields, but the highest economic return is obtained with $\mathrm{N}$ applied at $100 \mathrm{~kg} \mathrm{ha}^{-1}$ with conventional urea and inoculation, which can ensure profitability from production of irrigated corn in the Cerrado.

\section{References}

AGUIAR, R. A. D.; SILVEIRA, P. M. D.; MOREIRA, J. A. A.; WANDER, A. E. Análise econômica de diferentes práticas culturais na cultura do milho (Zea mays L.). Pesquisa Agropecuária Tropical, Goiânia, v. 38, n. 4, p. 241-248, 2008. 
BARASSI, C. A.; SUELDO, R. J.; CREUS, C. M.; CARROZZI, L.; CASANOVAS, E. M.; PEREYRA, M. A. Potencialidad de Azospirillum en optimizer el crecimiento vegetal bajo condiciones adversas. In: CASSÁN, F. D.; GARCIA DE SALAMONE, I. (Ed.). Azospirillum ssp.: cell physiology, plant interactions and agronomic research in Argentina. Buenos Aires: Asociación Argentina de Microbiologia, 2008. p. 49-59.

BASHAN, Y.; BUSTILLOS, J. J.; LEYVA, L. A.; HERNANDEZ, J. P.; BACILIO, M. Increase in auxiliary photoprotective photosynthetic pigmentsin wheat seedlings induced by Azospirillum brasilense. Biology and Fertility of Soils, Berlin, v. 42, n. 4, p. 279-285, 2006.

CANTARELLA, H. Nitrogênio. In: NOVAIS, R. F.; ALVAREZ, V.; BARROS, N. F.; FONTES, R. L. F.; CANTARUTTI, R. B.; NEVES, J. C. L. (Ed.). Fertilidade do solo. Viçosa, MG: Sociedade Brasileira de Ciência do Solo, 2007. cap. 7, p. 375-470.

CANTARELlA, H.; RAIJ, B. Van; CAMARGO, C. E. O. Cereais. In: RAIJ, B. Van; CANTARELLA, H.; QUAGGIO, J. A.; FURLANI, A. M. C. Recomendações de calagem e adubação para o Estado de São Paulo. Campinas: Instituto Agronômico de Campinas, 1997. 285 p. (Boletim técnico, 100).

CANTARELLA, H.; TRIVELIN, P. C. O.; CONTIN, T. L. M.; DIAS, F. L. F.; ROSSETTO, R.; MARCELINO, R.; COIMBRA, R. B.; QUAGGIO, J. A. Ammonia volatilisation from urease inhibitor-treated urea applied to sugarcane trash blankets. Scientia Agricola, Piracicaba, v. 65 , n. 4, p. 397-401, 2008.

CAVAlLET, L. E.; PESSOA, A. C. S.; HELMICH, J. J.; HELMICH, P. R.; OST, C. F. Produtividade do milho em resposta à aplicação de nitrogênio e inoculação das sementes com Azospirillum spp. Revista Brasileira de Engenharia Agrícola e Ambiental, Campina Grande, v. 4, n. 1, p. 129-132, 2000.

CRUZ, C. D.; CARNEIRO, P. C. S. Modelos biométricos aplicados ao melhoramento genético. Viçosa, MG: UFV, 2003. $579 \mathrm{p}$.

DUETE, R. R. C.; MURAOKA, T.; SILVA, E.; TREVELIN, P.; AMBROSANO, E. J. Viabilidade econômica de doses e parcelamentos da adubação nitrogenada na cultura do milho em Latossolo Vermelho Eutrófico. Acta Scientiarum Agronomy, Maringá, v. 31, n. 1 , p. $175-181,2009$.

GALINDO, F. S.; TEIXEIRA FILHO, M. C. M.; BUZETTI, S.; SANTINI, J. M. K.; ALVES, C. J.; NOGUEIRA, L. M.; LUDKIEWICZ, M. G. Z.; ANDREOTTI, M.; BELLOTE, J. L. M. Corn yield and foliar diagnosis affected by nitrogen fertilization and inoculation with Azospirillum brasilense. Revista Brasileira de Ciência do Solo, Viçosa, MG, v. 40, n. 1, p. e015036, 2016.

GALINDO, F. S.; TEIXEIRA FILHO, M. C. M.; BUZETTI, S.; SANTINI, J. M. K.; LUDKIEWICZ, M. G. Z.; BAGGIO, G. Modes of application of cobalt, molybdenum and Azospirillum brasilense on soybean yield and profitability. Revista Brasileira de Engenharia Agrícola e Ambiental, Campina Grande, v. 21, n. 3, p. 180-185, 2017.

GARCIA, C. M. P.; ANDREOTTI, M.; TARSITANO, M. A. A.; TEIXEIRA FILHO, M. C. M.; LIMA, A. E. S.; BUZETTI, S. Análise econômica da produtividade de grãos de milho consorciado com forrageiras dos gêneros Brachiaria e Panicum em sistema plantio direto. Revista Ceres, Viçosa, MG, v. 59, n. 2, p. 157-163, 2012.

GOMES, R. F.; SILVA, A. G. da; ASSIS, R. L. de; PIRES, F. R. Efeito de doses e da época de aplicação de nitrogênio nos caracteres agronômicos da cultura do milho sob plantio direto. Revista Brasileira de Ciência do Solo, Viçosa, MG, v. 31, n. 5, p. 931-938, 2007.

HUNGRIA, M. Inoculação com Azospirillum brasilense: inovação em rendimento a baixo custo. Londrina: Embrapa Soja, 2011. 37 p. (Embrapa Soja. Documentos, 325).

INSTITUTO DE ECONOMIA AGRÍCOLA - IEA. Banco de dados. [S.1.: s.n.], 2016. Disponível em: $<$ http:// www.iea.sp.gov.br/out/bancodedados.html $>$. Acesso em: 9 mar. 2017.

KANEKO, F. H.; ARF, O.; GITTI, D. C.; TARSITANO, M. A. A.; RAPASSI, R. M. A.; VILELA, R. G. Custos e rentabilidade do milho em função do manejo do solo e da adubação nitrogenada. Pesquisa Agropecuária Tropical, Goiânia, v. 40, n. 1, p. 102-109, 2010.

KANEKO, F. H.; LEAL, A. J. F. Estimativa do custo de produção da cultura do milho na região dos Chapadões, safra 2009/10. Pesquisa - Tecnologia - Produtividade, Chapadão do Sul, v. 3, n. 1, p. 128-134, 2010.

KANEKO, F. H.; SABUNDJIAN, M. T.; ARF, O.; FERREIRA, J. P.; GITTI, D. C.; NASCIMENTO, V.; LEAL, A. J. F. Análise econômica do milho em função da inoculação com Azospirillum, fontes e doses de $\mathrm{N}$ em cerrado de baixa altitude. Revista Brasileira de Milho e Sorgo, Sete Lagoas, v. 14, n. 1, p. 23-37, 2015.

KAPPES, C.; ARF, O.; ARF, M. V.; FERREIRA, J. P.; DAL BEM, E. A.; PORTUGAL, J. R.; VILELA, R. G. Inoculação de sementes com bactéria diazotrófica e aplicação de nitrogênio em cobertura e foliar em milho. Semina: Ciências Agrárias, Londrina, v. 34, n. 2, p. $527-$ 538, 2013. 
KAPPES, C.; GITTI, D. C.; ARF, O.; ANDRADE, J. A. C.; TARSITANO, M. A. A. Análise econômica do milho em sucessão a diferentes adubos verdes, manejos do solo e doses de nitrogênio. Bioscience Journal, Uberlândia, v. 31, n. 1, p. 55-64, 2015.

LADHA, J. K.; PATHAK, H.; KRUPNIK, T. J.; SIX, J.; KESSEL, C. V. Efficiency of fertilizer nitrogen in cereal production: restropects and prospects. Advances in Agronomy, Oxford, v. 87, p. 85-156, 2005.

LEAL, S. T.; TARSITANO, M. A. A.; GOES, R. J.; TAKASU, A. T.; RODRIGUES, R. A. F.; ARF, O.; ROSSETTO, J. É.; LEAL, C. C. Análise econômica da produção de sorgo na safrinha com diferentes fontes de nitrogênio em cobertura. Revista Brasileira de Milho e Sorgo, Sete Lagoas, v. 12, n. 2, p. 85-91, 2013.

MAESTRELO, P. R.; BUZETTI, S.; TEIXEIRA FILHO, M. C. M.; GARCIA, C. M. P.; RODRIGUES, M. A. C.; LINO, A. C. M.; ANDREOTTI, M. Aplicação de ureia revestida em cobertura no milho irrigado sob sistema de semeadura direta. Agrária - Revista Brasileira de Ciências Agrárias, Recife, v. 9, n. 2, p. 192-199, 2014.

MARTIN, N. B.; SERRA, R.; OLIVEIRA, M. D. M.; ÂNGELO, J. A.; OKAWA, H. Sistema integrado de custos agropecuários - CUSTAGRI. Informações Econômicas, São Paulo, v. 28, n. 1, p. 7-28, 1998.

MATSUNAGA, M.; BEMELMANS, P. F.; TOLEDO, P. N. E.; DULLEY, R. D.; OKAWA, H.; PEDROSO, I. A. Metodologia de custo de produção utilizada pelo IEA. Agricultura em São Paulo, São Paulo, v. 23, n. 1, p. 123139, 1976.

MOHAMMADI, S. A.; PRASANNA, B. M.; SINGH, N. N. Sequential path model for determining interrelationship among grain yield related characters in maize. Crop Science, Madison, v. 43, n. 5, p. 690-697, 2003.

NUNES, P. H. M. P.; AQUINO, L. A.; SANTOS, L. P. D. dos; XAVIER, F. O.; DEZORDI, L. R.; ASSUNÇÃO, N. S. Produtividade do trigo irrigado submetido à aplicação de nitrogênio e à inoculação com Azospirillum brasilense. Revista Brasileira de Ciência do Solo, Viçosa, MG, v. 39, n. 1, p. 174-182, 2015.

OHLAND, R. A. A.; SOUZA, L. C. F.; HERNANI, L. C.; MARCHETTI, M. E.; GONÇALVES, M. C. Culturas de cobertura do solo e adubação nitrogenada no milho em plantio direto. Ciência e Agrotecnologia, Lavras, v. 29, n. 3, p. 538-544, 2005.

PORTUGAL, J. R.; TARSITANO, M. A. A.; PERES, A. R.; ARF, O.; GITTI, D. C. Organic and mineral fertilizer application in upland rice irrigated by sprinkler irrigation: economic analysis. Cientifica, Jaboticabal, v. 44, n. 2, p. 146-155, 2016.

RAIJ, B. Van; ANDRADE, J. C.; CANTARELLA, H.; QUAGGIO, J. A. Análise química para avaliação da fertilidade de solos tropicais. Campinas: IAC, 2001. 285 p.

SANTOS, H. G.; JACOMINE, P. K. T.; ANJOS, L. H. C.; OLIVEIRA, V. A.; LUMBRERAS, J. F.; COELHO, M. R.; ALMEIDA, J. A.; CUNHA, T. J. F.; OLIVEIRA, J. B. Sistema brasileiro de classificação de solos. 3. ed. Brasília: EMBRAPA, 2013. 353 p.

SCIVITTARO, W. B.; GONÇALVES, D. R. N.; VALE, M. L. C. do; RICORDI, V. G. Perdas de nitrogênio por volatilização de amônia e resposta do arroz irrigado à aplicação de ureia tratada com o inibidor de urease NBPT. Ciência Rural, Santa Maria, v. 40, n. 6, p. 12831289, 2010.

SILVA, E. C.; BUZETTI, S.; LAZARINI, E. Aspectos econômicos da adubação nitrogenada na cultura do milho em sistema plantio direto em Latossolo Vemelho distroférrico fase Cerrado. Revista Brasileira de Milho e Sorgo, Sete Lagoas, v. 4, n. 3, p. 286-297, 2005.

SILVA, E. C.; MURAOKA, T.; MONTEIRO, R. O. C.; BUZETTI, S. Análise econômica da adubação nitrogenada no milho sob plantio direto em sucessão a plantas de cobertura em Latossolo Vermelho. Acta Scientiarum. Agronomy, Maringá, v. 29, n. 4, p. 445-452, 2007.

SORATTO, R. P.; PEREIRA, M.; COSTA, T. A. M.; LAMPERT, V. N. Fontes alternativas e doses de nitrogênio no milho safrinha em sucessão à soja. Revista Ciência Agronômica, Fortaleza, v. 41, n. 4, p. 511-518, 2010.

SOUZA, J. A.; BUZETTI, S.; TEIXEIRA FILHO, M. C. M.; ANDREOTTI, M.; SÁ, M. E.; ARF, O. Adubação nitrogenada na cultura do milho safrinha irrigado em plantio direto. Bragantia, Campinas, v. 70, n. 2, p. 447454, 2011.

TEIXEIRA FILHO, M. C. M.; BUZETTI, S.; ANDREOTTI, M.; BENETT, C. G. S.; ARF, O.; SÁ, M. E. Wheat nitrogen fertilization under no till on the low altitude brazilian Cerrado, Journal of Plant Nutrition, New York, v. 37, n. 11, p. 1732-1748, 2014.

TIEN, T. M.; GASKINS, M. H.; HUBBELL, D. H. Plant growth substances produced by Azospirillum brasilense and their effect on the growth of pearl millet (Pennisetum americanum L.). Applied and Environmental Microbiology, Washington, v. 37, n. 5, p. 1016-1024, 1979. 
ULGER, A. C.; BECKER, A. C.; KHANT, G. Response of maize inbred lines and hybrids to increasing rates of nitrogen fertilizer. Journal of Agronomy and Crop Science, Berlin, v. 159, n. 1, p. 157-163, 1995.
VALDERRAMA, M.; BUZETTI, S.; BENETT, C. G. S.; ANDREOTTI, M.; TEIXEIRA FILHO, M. C. M. Fontes e doses de NPK em milho irrigado sob plantio direto. Pesquisa Agropecuária Tropical, Goiânia, v. 41, n. 2, p. 254-263, 2011. 